\title{
АКТУАЛЬНІ ПИТАННЯ АДМІНІСТРАТИВНОЇ ЮРИСДИКЦІї ОРГАНІВ, ПІДРОЗДІЛІВ НАЦІОНАЛЬНОЇ ПОЛІЦІЇ 3 ОХОРОНИ НАВКОЛИШНЬОГО ПРИРОДНОГО СЕРЕДОВИЩА В СУЧАСНИХ УМОВАХ
}

Гусаров С. М.

\begin{abstract}
У статті визначається значимість і актуальність охорони навколишнього природного середовища для людини і суспільства, зазначено недоліки державного управління і контролю в чій сфері, розглянуто теоретичні підходи до розуміння «юрисдикції», наведено власне визначення «адміністративної юрисдикції органів, підрозділів Національноі поліції у сфері охорони навколишнього природного середовища», розглянуто участь органів, підрозділів Національноі поліції України в охороні навколишнього природного середовища та особливості їхньої адміністративної юрисдикції у чіŭ сфері.

Ключові слова: адміністративна юрисдикція, органи, підрозділи Національної поліції, адміністративні правопорушення, охорона навколишнього природного середовища.
\end{abstract}

В статье определяется значимость и актуальность охраны окружающей природной среды для человека и обще ства, указаны недостатки государственного управления и контроля в этой сфере, рассмотрены теоретические подходы к пониманию «юрисдикции», приведено собственное определение «административной юрисдикции органов, подразделений Национальной полиции в сфере охраны окружающей природной среды», рассмотрено участие органов, подразделений Национальной поличии Украины в охране окружающей природной среды и особенности их админи стативной юрисдикции в этой сфере.

Ключевые слова: административная юрисдикция, органы, подразделения Национальной полиции, административные правонарушения, охрана окружающей среды.

The article determines the importance and urgency of environmental protection for the individual and society, defines the deficiencies of public administration and control in this field, discusses theoretical approaches to understanding "jurisdiction", describes the own definition of "administrative jurisdiction of bodies, units of the National Police in the field of environmental protection", the participation of bodies, units of the National Police of Ukraine in the environmental protection and features of their administrative jurisdiction in this area.

Attention is paid to the lack of a clear legal and regulatory definition of the tasks, functions, competencies, powers, and forms of cooperation of bodies, units of the National Police with other state bodies, services, inspections, local self-government bodies, public formations on certain issues, which cause the ineffective activity of the National Police in the field of environmental protection.

The state of application of articles 80 and 81 of the Code of Ukraine on Administrative Offenses (in relation to exceedance of the standards of the content of pollutants in the exhaust gases of vehicles) by the units of patrol police is analyzed and it is found out that these norms are not applied in practice today due to the lack of certified devices for measuring exceedance

Гусаров С. М., 2019 of the standards of the content of pollutants in the exhaust gases of vehicles.

The article justifies and supports the opinion of other scientists on the formation of environmental police in Ukraine, the legal regulation of its administrative and jurisdictional activities, taking into account the experience of similar police structures in other countries.

The need to expand the administrative and jurisdictional activity of the currently operating bodies, units of the National Police in the field of environmental protection, above all, of police officers and patrol police, is being proved.

Key words: administrative jurisdiction, bodies, units of the National Police, administrative offenses, environmental protection.

Постановка проблеми. Охорона навколишнього природного середовища, раціональне використання природних ресурсів, забезпечення екологічної безпеки життєдіяльності людини - невід'ємна умова сталого економічного та соціального розвитку України [1]. Тому потреба у зміні ставлення людства до навколишнього природного середовища, до ресурсів землі, збереження ії багатств сьогодні не викликає сумнівів.

У ст. 16 Конституції України визначається, що забезпечення екологічної безпеки і підтримання екологічної рівноваги на території України, подолання наслідків Чорнобильської катастрофи - катастрофи планетарного масштабу, збереження генофонду Українського народу $\epsilon$ обов'язком держави [2], а відтак і державних органів, серед яких визначальне значення слід відвести органам Національної поліції.

Без перебільшення можна сказати, що проблема охорони навколишнього природного середовища набула нового сприйняття і стала однією з найактуальніших проблем сьогодення, яка безпосередньо пов'язана з виживанням людства.

Конституцією України визначається і гарантується, що кожен має право на безпечне для життя і здоров'я довкілля та на відшкодування завданої порушенням цього права шкоди. Кожному гарантується право вільного доступу до інформації про стан довкілля, про якість харчових продуктів і предметів побуту, а також право на їі поширення. Така інформація ніким не може бути засекречена (ст. 50) [2].

Ураховуючи значимість i актуальність охорони навколишнього природного середовища для людини і суспільства, система державного контролю у цій сфері постійно піддається критиці як із боку держави, так і з боку громадськості, у зв'язку із чим владою заявлено курс на перегляд наявного державного управління та контролю. В Україні відсутній прозорий механізм 


\section{Актуальні проблеми історико-правової та міжнародно-правової науки}

проведення моніторингу стану навколишнього природного середовища та доступу до великої кількості екологічних даних, що повинні бути відкритими [3]. Відтак удосконалення контролю у сфері навколишнього природного середовища потребує суттєвого покращення взаємодії профільних державних органів у природоохоронній сфері із правоохоронними органами України, зокрема з органами, підрозділами Національної поліції та розширення компетенції і повноважень останніх із природоохоронних питань.

Стан дослідження. Окремим питанням охорони навколишнього природного середовища присвятили свої наукові праці Б.М. Гамалюк, С.Г. Грицкевич, С.М. Гусаров, Н.І. Золотарьова, Д.П. Іванюк, І.Д. Казанчук, Н.В. Лебідь, Н.В. Марфіна, В.І. Самкнулов, О.М. Хіміч, Ю.С. Шемшученко, І.В. Шульга, В.В. Янчук та інші. Однак питанням адміністративної юрисдикції органів, підрозділів Національної поліції з охорони навколишнього природного середовища в сучасних умовах приділено недостатньо уваги, чітке визначення цих питань у нормативно-правових актах відсутнє, що й зумовлює необхідність дослідження цих питань.

Метою статті $\epsilon$ розгляд стану адміністративної юрисдикції органів, підрозділів Національної поліції з охорони навколишнього природного середовища в Україні.

Виклад основного матеріалу. Виконання функції щодо охорони навколишнього природного середовища покладено на відповідні органи державної влади та місцевого самоврядування.

Аналіз нормативно-правових актів із природоохоронної та екологічної безпеки України дає можливість суб'єкти охорони природного середовища за змістом повноважень поділяти на органи: законодавчої влади, уповноважені органи виконавчої влади, місцевого самоврядування і спеціально створені (уповноважені) природоохоронні органи. Особливе місце серед цих суб'єктів займають спеціально уповноважені органи виконавчої влади - Міністерство енергетики та захисту довкілля, Держгеокадастр, Державне агентство земельних ресурсів України, Державне агентство водних ресурсів України, Державне агентство лісових ресурсів України, Державна екологічна інспекція та інші.

Органи і підрозділи Національної поліції законодавець не відносить до спеціальних органів у сфері охорони навколишнього природного середовища, їхнє основне призначення - служити суспільству шляхом забезпечення охорони прав і свобод людини, протидії злочинності, підтримання публічної безпеки і порядку (ст. 1) [4]. Водночас вони також наділені певною адміністративною юрисдикцією з охорони навколишнього природного середовища, хоча їхня діяльність із цього напряму $\epsilon$ недостатньо урегульованою, а відтак - малоефективною.

Адміністративна юрисдикція органів, підрозділів Національної поліції у сфері охорони навколишнього природного середовища потребує теоретичного дослідження та практичного удосконалення з ряду причин: по-перше, в юридичній літературі відсутній єдиний підхід щодо визначення змісту поняття «адміністративна юрисдикція», що суттєво впливає на обсяг предмета наукового дослідження та коло суб'єктів адміністративно-юрисдикційної діяльності; по-друге, визначення підвідомчості справ про адміністративні правопорушення потребує вдосконалення, що змушує науковців досліджувати ці проблеми.
В юридичній енциклопедіївизначається, що юрисдикція (лат. jurisdictio - судочинство, від jus (juris) - право i dicere - говорити, проголошувати) - 1) встановлена законодавством сукупність повноважень відповідних органів державної влади та органів місцевого самоврядування розглядати та вирішувати правові спори і справи про правопорушення, давати правову оцінку діянням осіб або інших суб'єктів права з т. з. їх правомірності або неправомірності, застосовувати санкції до правопорушників. За характером справ, які розглядаються, юрисдикція може бути адміністративною, конституційною та ін.; 2) територіальні межі компетенційної сфери діяльності певних органів державної влади або органів місцевого самоврядування. Юрисдикція може визначатися за територією, на яку поширюються повноваження того чи ін. публічно-владного органу (напр., за місцем скоєння злочину або за місцем мешкання відповідача); 3) відправлення правосуддя або підсудність. У даному випадку зміст юрисдикції полягає в реалізації судом повноважень: а) керувати судовим процесом; б) судити і виносити компетентне рішення; в) зобов'язувати до виконання рішення, що прийняте. Юрисдикція судів може визначатися особливостями кола осіб, які $\epsilon$ учасниками судового розгляду справи (напр., підсудність військовослужбовців військ. судам); 4) у міжнародному праві розрізняють юрисдикцію держави та міжнародну. Юрисдикція держави поділяється на територіальну та особисту (національну). Юрисдикція територіальна зумовлюється суверенністю влади держави в межах ii території, де вона має абсолютну юрисдикцію, за винятком випадків, коли відповідно до міжнародних угод не передбачається інше. Особиста (національна) юрисдикція держави поширюється на своїх громадян, які перебувають за межами її території (напр., у відкритому морі). В окремих випадках, передбачених національним законодавством, юрисдикція держави поширюється на громадян цієї держави, які перебувають на території іншої держави, однак здійснюватися така юрисдикція може лише на території своєї держави, якщо інше не передбачено міжнародними угодами. Юрисдикція міжнародна - це підсудність певної категорії справ міжнародним органам. Даний вид юрисдикції, на відміну від юрисдикції держави, $є$ певним обмеженням державного суверенітету. Цей фактор зумовлює те, що для визнання юрисдикції будь-якого міжнародного органу необхідна явно виражена згода відповідної держави. Так, згідно зі ст. 36 Статуту Міжнародного суду ООН держави можуть (але не зобов'язані) заявити про обов'язковість для себе юрисдикції Міжнародного суду. До цього часу більшість держав не визнали його юрисдикції як обов'язкову для себе [5, с. 490].

Питання адміністративної юрисдикції в різні періоди розглядались Б. Авер'яновим, Т. Коломоєць, Г. Корчемним, М. Максютіним, І. Голосніченко, В. Грохольським, В. Колпаковим, Л. Анохіною, Д. Калаяновим, А. Комзюком, В. Курило, С. Тараненко А. Шергіним, Х. Ярмакі та ін.

Зокрема, аналізуючи думки науковців щодо змісту адміністративної юрисдикції, Г.М. Корчемний поділяє їх на три основні групи. До першої групи він відносить погляди науковців, які під адміністративною юрисдикцією розуміють тільки розгляд і вирішення справ про адміністративні правопорушення. Другий підхід полягає в тому, що адміністративна юрисдикція, окрім 
означеного, включає в себе також групу заходів адміністративного припинення і забезпечення провадження у справах про адміністративні правопорушення, а також іншу діяльність компетентних органів, пов'язану з притягненням особи до адміністративної відповідальності (наприклад, складання протоколу про адміністративне правопорушення). Третій підхід полягає в тому, що адміністративна юрисдикція розглядається як діяльність компетентних органів (службових осіб) із застосування заходів адміністративно-правового примусу. Тобто у зміст адміністративної юрисдикції, на відміну від другого підходу, включається також і діяльність із застосування заходів адміністративного попередження (контрольні перевірки, встановлення карантину, перевірка документів тощо) [6].

Автори підручника «Адміністративна юрисдикція в АПК України» зазначають, що юрисдикція як вид діяльності органів державної влади безпосередньо пов'язана з охороною суспільних відносин і полягає в розгляді органами державної влади справи по суті та прийнятті рішення, виконання якого може забезпечуватися примусовою силою держави. Адміністративна юрисдикція $\epsilon$ одним із видів юрисдикційної діяльності органів державної влади і виступає як складова частина реалізації виконавчої влади. У процесі здійснення адміністративної юрисдикції забезпечується охорона певних соціальних благ і цінностей (громадського порядку, суспільної безпеки, прав і свобод громадян) шляхом проведення розслідування, обвинувачення особи, винної у здійсненні протиправного діяння; розгляду справи про це діяння, винесення по ньому рішення про застосування (або незастосування) адміністративного стягнення, виконання рішення, яке винесене [7, с. 99].

Таким чином, узагальнивши думки науковців, можемо зробити висновок, що адміністративну юрисдикцію органів, підрозділів Національної поліції у сфері охорони навколишнього природного середовища ми розглядаємо як вид правоохоронної діяльності, безпосередньо пов'язаної з охороною суспільних відносин у сфері охорони навколишнього природного середовища, яка полягає в застосуванні норм права, прийнятті рішення та його реалізації відносно правопорушників, виконання якого може забезпечуватися примусовою силою держави.

Важливим аспектом у сфері охорони навколишнього природного середовища $\epsilon$ діяльність, спрямована на протидію правопорушенням у зазначеній сфері саме органів, підрозділів Національної поліції. Оскільки органи, підрозділи Національної поліції $\epsilon$ основною державною інституцією у сфері забезпечення правопорядку, то наділення їх додатковою компетенцією і повноваженнями у сфері охорони навколишнього природного середовища сприятиме тільки підвищенню рівня захисту навколишнього природного середовища.

Сьогодні, поки що, ми констатуємо недостатнє нормативно-правове визначення компетенції органів, підрозділів Національної поліції у сфері охорони навколишнього природного середовища. У Законі України «Про Національну поліцію» визначаються тільки загальні завданнями поліції, до яких віднесено надання поліцейських послуг у сферах:

1) забезпечення публічної безпеки і порядку;

2) охорони прав і свобод людини, а також інтересів суспільства і держави;
3) протидії злочинності;

4) надання в межах, визначених законом, послуг із допомоги особам, які з особистих, економічних, соціальних причин або внаслідок надзвичайних ситуацій потребують такої допомоги [4].

Для виконання поставлених завдань Національна поліція наділена певними повноваженнями, які, можна віднести і до охорони навколишнього природного середовища, а саме:

- здійснює превентивну та профілактичну діяльність, спрямовану на запобігання вчиненню правопорушень;

- виявляє причини та умови, що сприяють вчиненню кримінальних та адміністративних правопорушень, вживає в межах своєї компетенції заходи для їх усунення;

- вживає заходи з метою виявлення кримінальних, адміністративних правопорушень; припиняє виявлені кримінальні та адміністративні правопорушення;

- здійснює своєчасне реагування на заяви та повідомлення про кримінальні, адміністративні правопорушення або події;

- у випадках, визначених законом, здійснює провадження у справах про адміністративні правопорушення, приймає рішення про застосування адміністративних стягнень та забезпечує їх виконання;

- доставляє у випадках i порядку, визначених законом, затриманих осіб, підозрюваних у вчиненні кримінального правопорушення, та осіб, які вчинили адміністративне правопорушення;

- вживає заходи для забезпечення публічної безпеки і порядку на вулицях, площах, у парках, скверах, на стадіонах, вокзалах, в аеропортах, морських та річкових портах, інших публічних місцях;

- регулює дорожній рух та здійснює контроль за дотриманням Правил дорожнього руху його учасниками та за правомірністю експлуатації транспортних засобів на вулично-дорожній мережі;

- здійснює супроводження транспортних засобів у випадках, визначених законом;

- видає відповідно до закону дозволи на рух окремих категорій транспортних засобів; у випадках, визначених законом, видає та погоджує дозвільні документи у сфері безпеки дорожнього руху;

- здійснює охорону об'єктів права державної власності у випадках та порядку, визначених законом та іншими нормативно-правовими актами, а також бере участь у здійсненні державної охорони;

- здійснює контроль у межах своєї компетенції, визначеної законом, за дотриманням вимог режиму радіаційної безпеки у спеціально визначеній зоні радіоактивного забруднення;

- сприяє забезпеченню відповідно до закону правового режиму воєнного або надзвичайного стану, зони надзвичайної екологічної ситуації у разі їх оголошення на всій території України або в окремій місцевості (ст. 23) [4].

Слід відмітити, що в рамках визначених завдань, компетенції та повноважень органами, підрозділами Національної поліції з певною періодичністю, в межах взаємодії із працівниками Державного агентства водних ресурсів України, Державного агентства лісових ресурсів України, Державної екологічної інспекції, 3 метою захисту відповідних об'єктів навколишнього природного середовища проводяться такі операції, як, 
наприклад: «Новорічна ялинка», «Первоцвіт», «Полювання», «Нерест» та ін.

Проте, зважаючи на відсутність чіткого нормативно-правового визначення завдань, компетенції, повноважень, функцій і форм взаємодії органів, підрозділів Національної поліції з іншими державними органами, службами, інспекціями, органами місцевого самоврядування, громадськими формуваннями з визначених питань, ефективність діяльності Національної поліції у сфері охорони навколишнього природного середовища видається нам малоефективною та проблематичною.

Аналіз нормативно-правових актів, що регламентують діяльність Національної поліції, свідчить, що адміністративно-юрисдикційні повноваження із проведення окремих заходів з охорони навколишнього природного середовища в основному покладається на окремі підрозділи превентивної діяльності, а саме патрульну поліцію, підрозділи дозвільної системи та дільничних офіцерів поліції. Зокрема, відповідно до ст. 222 КУпАП органи Національної поліції розглядають справи за ст. 80 КУпАП «Випуск в експлуатацію транспортних та інших пересувних засобів із перевищенням нормативів вмісту забруднюючих речовин у відпрацьованих газах» і ст. 81 КУпАП «Експлуатація автомототранспортних та інших пересувних засобів із перевищенням нормативів вмісту забруднюючих речовин у відпрацьованих газах» (у частині перевищення нормативів вмісту забруднюючих речовин у відпрацьованих газах транспортних засобів).

Від імені органів Національної поліції розглядати справи про адміністративні правопорушення і накладати адміністративні стягнення мають право працівники органів і підрозділів Національної поліції, які мають спеціальні звання відповідно до покладених на них повноважень [8].

У разі виявлення правопорушення у сфері забезпечення безпеки дорожнього руху, розгляд якого віднесено до компетенції Національної поліції України, поліцейський виносить постанову у справі про адміністративне правопорушення без складання відповідного протоколу. Постанова виноситься в разі виявлення адміністративних правопорушень у сфері забезпечення безпеки дорожнього руху, зокрема, передбачених статтями 80 і 81 КУпАП (в частині перевищення нормативів вмісту забруднюючих речовин у відпрацьованих газах транспортних засобів) [9].

Вивчення й аналіз стану застосування статей 80 і 81 КУпАП (у частині перевищення нормативів вмісту забруднюючих речовин у відпрацьованих газах транспортних засобів) підрозділами Національної поліції свідчить, що зазначені норми сьогодні на практиці не застосовуються у зв'язку з відсутністю сертифікованих приладів із виміру перевищення нормативів вмісту забруднюючих речовин у відпрацьованих газах транспортних засобів, що дає можливість власникам автомототранспортних та інших пересувних засобів отруювати навколишнє природне середовище та негативно впливати на стан здоров'я населення.

Сьогодні органи, підрозділи Національної поліції позбавлені широкого кола адміністративно-юрисдикційних повноважень у сфері охорони навколишнього природного середовища. Наприклад, працівники цих органів і підрозділів не наділені компетенцією та повноваженнями щодо протидії адміністративним правопорушенням, визначеним у ст. 153 КУпАП «Зни- щення або пошкодження зелених насаджень або інших об'єктів озеленення в межах населених пунктів та за їх межами, що не віднесені до лісового фонду», що, на нашу думку, суттєво погіршує стан захисту навколишнього природного середовища, особливо в містах. Те ж саме стосується і цілої низки інших адміністративних правопорушень у галузі охорони навколишнього природного середовища, протидіяти яким працівники органів, підрозділів Національної поліції не мають адміністративно-юрисдикційних повноважень.

Тому ми погоджуємось із думкою науковців, що, враховуючи досвід діяльності поліцейських структур інших країн, в Україні доцільно створити екологічну поліцію [10]. Адміністративно-юрисдикційну діяльність таких підрозділів можна було б спрямовати на охорону навколишнього природного середовища зокрема, із протидії: 1) забрудненню території, що прилягає до підприємств, організацій, будівельних майданчиків, об'єктів торгівлі, вулиць, дворів, парків, бульварів, майданів, валів, ярів, водоохоронних зон водоймищ, зелених насаджень усіма видами промислових та побутових відходів; 2) звалищу побутових та промислових відходів, снігу в непередбачених для цього місцях; 3) забрудненню дорожнього покриття внаслідок порушення правил перевезення вантажів та експлуатації транспортних засобів, що перебувають у стані технічної несправності; 4) забрудненню майданчиків для збору сміття та територій навколо них, нагромадження (складування) товарів біля торговельних кіосків, наметів, павільйонів дрібнороздрібної торгівлі; 5) здійсненню всіх видів робіт, зокрема аварійних, пов'язаних із порушеннями благоустрою території, закриттям або обмеженням руху транспорту, пішоходів без дозволу відповідних організацій; 6) миттю автотранспорту у не відведених для цього місцях; 7) в'їзду транспортних засобів на газони, клумби, тротуари, територію парків, скверів, зелених зон; 8) нанесенню пошкоджень зеленим насадженням та пошкоджень, що спричинили їх загибель; 9) розпалюванню багать, спалювання сміття; 10) бездіяльності зелентрестів та інших організацій щодо своєчасного виявлення та підрізання (зрізання) сухих та пошкоджених дерев тощо. Окрім цього, доцільно забезпечити сертифікованими приладами з виміру перевищення нормативів вмісту забруднюючих речовин у відпрацьованих газах транспортних засобів патрульну поліцію з метою надання можливості застосовувати статті 80 і 81 КУпАП (у частині перевищення нормативів вмісту забруднюючих речовин у відпрацьованих газах транспортних засобів), розширити та конкретизувати повноваження дільничних офіцерів поліції з питань адміністративно-юрисдикційної діяльності з охорони навколишнього природного середовища.

Висновки. Підсумовуючи вищевикладене, можна сказати, що охорона навколишнього природного середовища потребує подальшого наукового дослідження з метою забезпечення комплексного підходу до вирішення цієї проблеми. Водночас у сучасних умовах розвитку нашого суспільства вбачається за необхідне створити підрозділи екологічної поліції з чітким визначенням на законодавчому рівні завдань, функцій, компетенції та повноважень, а також розширити адміністративно-юрисдикційну діяльність із охорони навколишнього природного середовища чинних органів, підрозділів Національної поліції, перш за все - дільничних 


\section{та міжнародно-правової науки}

офіцерів поліції та патрульної поліції, що сприятиме активізації протидії адміністративним правопорушенням у цій сфері та належному забезпеченню охорони навколишнього природного середовища.

\section{Література}

1. Про охорону навколишнього природного середовища : Закон України від 25.06.1991 р. № 1264-XII. Відомост Верховної Ради України, 1991. № 41. Ст. 546 (із змінами).

2. Конституція України. Відомості Верховної Ради України. 1996. № 30. Ст. 141.

3. Концепція реформування системи державного нагляду (контролю) у сфері охорони навколишнього природного середовища : затв. розпорядженням Кабінету Міністрів України від 31 травня 2017 р. № 616-p. URL : https://www.kmu.gov.ua/npas/250269536 (дата звернення: 25 березня 2020 р.).

4. Про Національну поліцію : Закон України від 02.07.2015 р. № 580-VIII. Відомості Верховної Ради. 2015. № 40-41. СТ. 379.

5. Юридична енциклопедія: у 6 т. / НАН України, Ін-т держави і права ім. В.М. Корецького НАН України, Вид-во «Українська енциклопедія» ім. М.П. Бажана. Київ : «Укр. енцикл.», 2004. Т. 6 : Т-Я. 768 с.
6. Корчемний Г.В. Адміністративно-юрисдикційна діяльність судів загальної юрисдикції. Судова апеляція. 2006. № 3. URL : htpp: //www.apcourtkiev.gov.ua/control-/ uk/publish/article?art_id=37189\&cat_id.

7. Курило В.І., Піддубний О.Ю., Кравчук М.Ю. Адміністративна юрисдикція в АПК України: підручник для студентів вищих навчальних закладів. Київ : Ірідіум, 2012. 248 c.

8. Кодекс України про адміністративні правопорушення: науково-практичний коментар. 8-е вид. Харків : ТОВ «Одисей», 2009. 1018 с.

9. Інструкція з оформлення поліцейськими матеріалів про адміністративні правопорушення у сфері забезпечення безпеки дорожнього руху, зафіксовані не в автоматичному режимі : затв. наказом МВС України від 07.11.2015 p. № 1395.

10. Казанчук І.Д. Компетенція органів Національної поліції України щодо охорони навколишнього середовища та екологічної безпеки в інтеграційних умовах. Haше право. 2017. № 1. С. 54-61.

Гусаров С. М., доктор юридичних наук, професор, заслужений юрист України 